\title{
LETTER TO THE EDITOR (MARCH 3, 2019) CONCERNING THE PAPER "THE RELATIONSHIP BETWEEN CHRONIC FATIGUE SYNDROME, BURNOUT, JOB SATISFACTION, SOCIAL SUPPORT AND AGE AMONG ACADEMICS AT A TERTIARY INSTITUTION"
}

Dear Editor,

Coetzee et al. [1] report on the relationship between job satisfaction, age and social support, and work-related health problems such as burn-out. The authors, however, seem to confuse chronic fatigue syndrome (CFS) with the more common symptom of long-lasting fatigue. The name might be somewhat confusing but only a minority of patients with chronic fatigue suffer from CFS [2].

The diagnosis of CFS requires a thorough examination by a physician and cannot be made on the basis of a questionnaire [3]. Patients who only satisfy the symptom criteria for CFS are usually referred to as "CFS-like" in the literature. Research has shown that most CFS-like patients have an exclusionary condition, and that only $14 \%$ [3] to $19 \%$ [4] suffer from CFS. Other reasons make it improbable that many CFS patients participated in the study by Coetzee et al. [1]. The authors examined only 69 persons working at an academic institution, while CFS has an estimated prevalence of $0.23 \%$ [3] to $0.42 \%$ [4]. Up to $75 \%$ of CFS patients are unable to work [5]. Even in the unlikely scenario where all 1433 employees at the academic institution received an invitation to participate in the study, and all CFS patients in this sample responded, the estimated total number of CFS patients would be no higher than 3. It is, therefore, questionable to present this paper as a study of CFS. One might argue that the use of the CDC symptom inventory [6] provides an insight into the prevalence of CFS symptoms in the workforce. Unfortunately, this seems unlikely as the questionnaire is substantially outdated. Several of the 19 symptoms listed, such as fever, diarrhea, chills, shortness of breath and sinus or nasal problems, are hardly characteristic of CFS. Even some of the "core symptoms," such as joint pain, headache, sore throat and tender lymph nodes, are no longer seen as defining elements in the diagnosis of this illness [7].

The suggestion by Coetzee et al. [1] that CFS is a workrelated illness should also be questioned. Case definitions of CFS require that disability is "not the result of ongoing exertion and is not substantially alleviated by rest" [7,8]. It is, therefore, improbable that CFS is related to work overload, as the authors claim. Research indicates that working night shifts before falling ill is not a risk factor for CFS severity [9]. Confusion might have originated from the term "yuppie flu," which frequently appeared in the media as a derogatory synonym of CFS. The name referred to "a fashionable form of hypochondria" [10] 
of highly-educated and mostly female professionals who were unable to meet their personal ambitions. Subsequent research has shown this to be a myth. Like many illnesses, CFS is more prevalent in lower socioeconomic classes [4], and the stereotype of CFS sufferers as perfectionists could not be confirmed [11,12].

Chronic fatigue syndrome has recently been redefined by the National Academy of Medicine [7]. The hallmark symptom of the illness is no longer considered to be fatigue, but post-exertional malaise (PEM): a significant symptom exacerbation that occurs each time patients exceed their current energy limit. This is relevant information for work providers. Postexertional malaise indicates that CFS patients are at risk of relapse when employed in an occupation that surpasses their physical or cognitive capabilities. Rehabilitative interventions have been demonstrated to be ineffective in increasing work resumption in CFS patients $[13,14]$.

\section{Key words: \\ chronic fatigue syndrome, post-exertional malaise, CDC symptom inventory, yuppie flu, relapse, work-related health problems}

\section{REFERENCES}

1. Coetzee N, Maree DJF, Smith BN. The relationship between chronic fatigue syndrome, burnout, job satisfaction, social support and age among academics at a tertiary institution. Int J Occup Med Environ Health. 2019;32(1):75-85, https://doi. org/10.13075/ijomeh.1896.01274.

2. Buchwald D, Umali P, Umali J, Kith P, Pearlman T, Komaroff AL. Chronic fatigue and the chronic fatigue syndrome: prevalence in a Pacific Northwest health care system. Ann Intern Med. 1995;123(2):81-8, https://doi.org/10.7326/00034819-123-2-199507150-00001.

3. Reyes M, Nisenbaum R, Hoaglin DC, Unger ER, Emmons C, Randall B, et al. Prevalence and incidence of chronic fatigue syndrome in Wichita, Kansas. Arch Intern Med. 2003;163(13): 1530-6, https://doi.org/10.1001/archinte.163.13.1530.
4. Jason LA, Richman JA, Rademaker AW, Jordan KM, Plioplys AV, Taylor RR, et al. A community-based study of chronic fatigue syndrome. Arch Intern Med. 1999;159(18): 2129-37, https://doi.org/10.1001/archinte.159.18.2129.

5. Pendergrast T, Brown A, Sunnquist M, Jantke R, Newton JL, Strand EB, et al. Housebound versus nonhousebound patients with myalgic encephalomyelitis and chronic fatigue syndrome. Chronic Illn. 2016;12(4):292-307, https:// doi.org/10.1177/1742395316644770.

6. Wagner D, Nisenbaum R, Heim C, Jones JF, Unger ER, Reeves WC. Psychometric properties of the CDC Symptom Inventory for assessment of chronic fatigue syndrome. Popul Health Metr. 2005;3:8, https://doi.org/10.1186/1478-7954-3-8.

7. Institute of Medicine. Beyond Myalgic Encephalomyelitis/ Chronic Fatigue Syndrome: Redefining an Illness [Internet]. Washington, D.C.: The National Academies Press; 2015 [cited 2019 Feb 2]. Available from: https://www.ncbi.nlm.nih. gov/books/NBK274235/.

8. Fukuda K, Straus SE, Hickie I, Sharpe MC, Dobbins JG, Komaroff A. The chronic fatigue syndrome: a comprehensive approach to its definition and study. International Chronic Fatigue Syndrome Study Group. Ann Intern Med. 1994;121(12):953-9, https://doi.org/10.7326/0003-4819-12112-199412150-00009.

9. Pheby D, Saffron L. Risk factors for severe ME/CFS. Biol Med. 2009;1:50-74.

10. Newsweek staff. Chronic fatigue syndrome [Internet]. Newsweek. 1990 Nov 11 [cited 2019 Feb 2]. Available from: https:// www.newsweek.com/chronic-fatigue-syndrome-205712.

11. Wood B, Wessely S. Personality and social attitudes in chronic fatigue syndrome. J Psychosom Res. 1999;47(4):385-97, https://doi.org/10.1016/S0022-3999(99)00025-2.

12. Loades ME, Rimes KA, Lievesley K, Ali S, Chalder T. Perfectionism and beliefs about emotions in adolescents with chronic fatigue syndrome and their parents: a preliminary investigation in a case control study nested within a cohort. Psychol Health. 2019:1-17, https://doi.org/10.1080/08870446. 2019.1579331. 
13. McCrone P, Sharpe M, Chalder T, Knapp M, Johnson AL, Michiel Tack Goldsmith KA, et al. Adaptive pacing, cognitive behavIndependent researcher, Oudenaarde, Belgium iour therapy, graded exercise, and specialist medical care for chronic fatigue syndrome: a cost-effectiveness analysis. PLoS One. 2012;7(8):e40808, https://doi.org/10.1371/journal.pone.0040808.

14. Prins JB, Bleijenberg G, Bazelmans E, Elving LD, de Boo TM, Severens JL, et al. Cognitive behaviour therapy for chronic fatigue syndrome: a multicentre randomised controlled trial. Lancet. 2001;357(9259):841-7, https://doi.org/ 10.1016/S0140-6736(00)04198-2.

This work is available in Open Access model and licensed under a Creative Commons Attribution-NonCommercial 3.0 Poland License - http://creativecommons.org/ licenses/by-nc/3.0/pl/deed.en. 